\title{
Representasi Rasisme Iklan Grab terhadap Ojek Pangkalan
}

\author{
Andika Anugrah \\ Program Studi Ilmu Komunikasi, Universitas Muhammadiyah Yogyakarta, Indonesia \\ andika.a.isip19@mail.umy.ac.id \\ Talitha Ailsa Ardiningrum \\ Program Studi Ilmu Komunikasi, Universitas Muhammadiyah Yogyakarta, Indonesia \\ talitha.ailsa.isip19@mail.umy.ac.id \\ Andhika Srindra Faiz Ramadhan \\ Program Studi Ilmu Komunikasi, Universitas Muhammadiyah Yogyakarta, Indonesia \\ andhika.s.isip19@mail.umy.ac.id \\ Diserahkan: 14 Juni 2021; Direvisi: 1 Juli 2021; Diterima: 9 Juli 2021
}

\begin{abstract}
This study aims to analyze the representation of marginalization of Grab ads against conventional Motorcycle Taxis. Where advertising has a big role in giving influence to the community. Ads are made based on representations of people's lives, this then becomes the reality of advertising. Advertising also has the power to build or change stereotypes in society. In this study, the authors analyzed Grab Ads. The research method used in this study is by descriptive qualitative research method with analysis method using semiotic method. Where this semiotic method analyzes based on the signs seen from the advertisement. The results of the analysis are then reviewed denominations and connotations. The results of this study have analyzed five scenes in The Grab Ad showing that there is a message of marjinalisasi in Grab's advertisements against conventional motorcycle taxis. In the ad, he said that the use of conventional motorcycle taxis is much more dangerous, and suggested to have an online ojek through grab. Thus, the message contained in this Grab Ad represents racism towards conventional motorcycle taxis.
\end{abstract}

Keywords: Advertising; Online Motorcycle Taxis; Conventional Motorcycle Taxis; Representation

\section{Abstrak}

Penelitian ini bertujuan untuk menganalisa representgasi marjinalisasi Iklan Grab terhadap Ojek konvensional. Dimana iklan memiliki peranan besar dalam memberikan pengaruh kepada masyarakat. Iklan dibuat berdasarkan pada representasi dari kehidupan masyarakat, hal ini kemudian menjadi realitas pada iklan. Iklan juga memiliki kekuatan dalam membangun ataupun merubah stereotype di masyarakat. Pada penelitian ini penulis menganalisa Iklan Grab. Metode penelitian yang digunakan dalam penelitian ini yaitu dengan metode penelitian kualitatif deskriptif dengan metode analisa menggunakan metode semiotika. Dimana metode semiotika ini menganalisa berdasarkan pada tanda-tanda yang dilihat dari iklan. Adapun hasil analisa tersebut kemudian diulas secara denotasi dan konotasi. Hasil penelitian ini telah menganalisa lima scene dalam Iklan Grab menunjukkan bahwasannya terdapat pesan marjinalisasi dalam iklan Grab terhadap ojek konvensional. Pada Iklan tersebut menyampaikan bahwasannya penggunaan ojek konvensional jauh lebih berbahaya, dan menyarankan untuk memilik ojek online melalui grab. Sehingga dengan demikian pesan yang ada dalam Iklan Grab ini merepresentasikan rasisme terhadap ojek konvensional.

Kata Kunci: Iklan; Ojek Online; Ojek Konvensional; Representasi 


\section{PENDAHULUAN}

Penelitian ini bertujuan untuk menganalisa representasi marjinalisasi pada iklan Grab terhadap Ojek Pangakan. Penelitian ini dilatarbelakangi terhadap perkembangan ojek. Pada sekitar tahun 1979, keberedaan ojek tidak disenangi oleh beberapa pihak termasuk diantaranya Gubernur Jakarta saat itu, Ali Sadikin. Pada tahun itu, banyak kepolisian yang mengadakan razia terhadap ojek-ojek. Namun, perkembangan dari jumlah pengendara ojek tidak dapat terkontrol dan terus meningkat. Hingga saat ini, transportasi ojek tidak termasuk ke dalam transportasi umum yang resmi di Indonesia. Dengan kemajuan teknologi yang makin pesat, kendaraan yang digunakan ojekpun semakin canggih. Tidak hanya sepeda motor bebek atau manual, tetapi sepeda motor matic sudah banyak digunakan. Tidak hanya kecanggihan dalam 52 kendaraannya saja, namun sistem ojekpun mengalami perkembangan seiring dengan kemajuan teknologi Internet khususnya di Indonesia.

Semenjak perusahaan GrabTaxi mengeluarkan aplikasi tranportasi berbasis online di Vietnam pada oktober 2014, PT Gojek Indonesia yang sudah berdiri sejak 2011 mulai melirik sistem online dan membuat aplikasi serupa pada awal Januari 2015. Kemudian disusul dengan GrabBike pada Mei 2015. Bagi masyarakat yang sudah melek teknologi, tentunya keberadaan ojek online atau transportasi online ini memberikan kemudahan dalam melakukan aktivitas sehari-hari. Dengan tarif yang relatif murah dan kemudahan dalam memesan ojek dimana saja, membuat ojek online ini banyak diminati oleh berbagai lapisan masyarakat.

Namun, tidak semua pihak menerima dengan baik keberadaan dari transportasi online ini. Para sopir angkutan umum, ojek pangkalan atau ojek konvensional, serta supir taksi banyak melakukan aksi protes penolakan adanya transportasi online. Tidak hanya aksi demo atau protes, namun para sopir angkutan umum, ojek pangakalan, serta supir taksi juga melakukan aksi anarkis dan juga kekerasan terhadap para driver transportasi online tersebut. Mereka menganggap bahwa ojek online tersebut telah merebut sumber penghasilan mereka sehari-hari karena banyak penumpang yang beralih menggunakan ojek online tersebut. Maka dari itu, konflik antara ojek online dengan ojek konvensional banyak terjadi dan tidak dapat dihindari. Terlebih lagi, Grab dinilai sering membuat iklan yang menggiring opini masyarakat bahwa ojek online Grab lebih aman dan terjangkau daripada Ojek Konvensional.

Hadirnya teknologi informasi, dan komunikasi merubah tatanan kehidupas secara fundamental manusia. Teknologi Internet muncul pertama kali pada tahun 1990-an sebagai konvergensi dari teknologi terdahulunya seperti komputer, televisi, radio, dan telepon. SaylingWen (2001) menjelaskan bahwa sekarang ini yang terpenting dan paling luas adalah Internet, yang menghubungkan komputer-komputer pribadi yang paling sederhana hingga jaringan komputer-komputer yang super canggih (Bungin, 2011). Secara umum, ada begitu banyak manfaat yang diperoleh jika seseorang mempunyai akses ke Internet. Di antaranya adalah informasi untuk kehidupan pribadi yang bersifat sehari-hari seperti dalam hal kesehatan, hobi, pengembangan pribadi, rohani dan sosial. Selain itu informasi untuk kehidupan profesional seperti keilmuan, teknologi, perdagangan, saham, komoditas, berita bisnis, asosiasi profesi, dan lain sebagainya.

Berkat kehebatan dari internet, maka situs kemudian menjadi sosok primadona dalam bidang komunikasi dan pemasaran. Tak ayal, bidang periklanan pun melihatnya sebagai media alternatif untuk mempromosikan sebuah produk ataupun media yang bertujuan untuk mengumpulkan massa. Melalui jaringannya yang luas dan mendunia, maka Internet tak pelak dijadikan pula sebagai media komunikasi utama untuk memperkenalkan sebuah brand atau produk baru di dunia periklanan

Iklan mempromosikan produk dalam tayangan media tertentu merupakan bagian dari upaya pemasaran yang signifikan dampaknya. Putra (2019) mengungkapkan pula peran iklan dan kesadaran khalayak pada merek tertentu terhadap minat beli konsumen. Hal ini juga dipengaruhi oleh kepiawaian 
sosok insan creator iklan dalam mengemas tindakan promosi tersebut sebagai fase yang harus dipahami secara seksama. Promosi produk melalui media televisi sebagai perantara, tentu berbeda dengan cara produser mempromosikan produk bisnis melalui media cetak atau koran atau bahkan melalui media internet yang menuntut adanya interaktifitas (Hariningsih, 2013). Semuanya tentu berbeda dan memiliki kelebihan dan kekurangan masing-masing.

Dikutip dalam buku Etika Pariwara Indonesia (2014) menuturkan bahwa hadirnya etika bukanlah untuk membatasi namun sebagai garis tepi arena periklanan, agar tidak melenceng dari tatanannya. Namun, masih ada beberapa insan pengiklan yang melanggar etika periklanan. Berbagai upaya dan beraneka ragam tindakan yang dapat ditempuh dalam rangka memperkenalkan sebuah produk yang dihasilkan oleh instansi, perusahaan atau lembaga tertentu. Salah satu tindakan yang kerap kita lihat, dengar, dan perhatikan melalui upaya tersebut tidak lebih dari sekedar berupa sosialisasi atau kegiatan promosi di pelbagai saluran media. Baik itu melalui media cetak, digital maupun elektronik. Berbagai aktivitas tersebut dilakukan untuk memperoleh hal yang ditargetkan di dalam pelaksanaan kegiatan industri tersebut.

\section{KAJIAN PUSTAKA}

\section{IKLAN}

Iklan merupakan salah satu bentuk khusus komunikasi yang biasanya digunakan pengusaha untuk mengarahkan komunikasi persuasi pada pembeli sasaran dan masyarakat. Periklanan merupakan suatu alat untuk membuka komunikasi dua arah antar penjual dengan pembeli, sehingga keinginan mereka dapat terpenuhi dengan cara yang efisien dan efektif. Iklan merupakan salah satu bentuk pesan yang disampaikan melalui media massa. Iklan bersifat mempersuasi khalayak, dengan harapan bahwa khalayak akan terpengaruh dengan isi iklan tersebut (Dapu, Kawengian, \& Waleleng, 2015).

Kritik terhadap iklan menyebutkan bahwa iklan bersifat menipu 'advertising is deceptive', namun sebenarnya iklan tidak menipu karena iklan sebenarnya menghindari klaim-klaim yang bersifat eksplisit yang dapat dinilai kejujurannya. Maka sebaliknya iklan menggunakan puffery (pujian yang berlebihan) dalam menekankan kebenaran (Potter, 2014).

Iklan juga bisa dikatakan tidak etis atau tidak pantas untuk ditayangkan. Seperti contoh-contoh sebelumnya adanya beberapa iklan yang ditarik peredarannya adalah karena alasan bahwa iklan tersebut tidak etis adapun beberapa hal yangbharus diperhatikan ketika sebuah iklan dikatakan tidak etis sebagai berikut (Gehi, 2013): (1) ketika sebuah iklan sudah menjatuhkan pesaingnya, atau produk saingnya; (2) ketika sebuah iklan memberikan informasi palsu yang dapat memberikan kesalahpahaman kepada publik mengenai sebuah produk; (3) ketika iklan tersebut memberikan informasi yang tidak bermanfaat mengenai produknya dan efek sampingnya; dan (4) ketika iklan tersebut tidak bermoral.

\section{REPRESENTASI}

Representasi berarti menggunakan bahasa untuk menyatakan sesuatu secara bermakna, atau mempresentasikan pada orang lain. Representasi merupakan bagian penting dalam proses di mana bahasa diproduksi dan dipertukarkan di antara simbol-simbol yang ada. Representasi melibatkan penggunaan bahasa dalam tanda-tanda (sign-sign) dan image-image yang mewakili atau mempresentasikan sesuatu (Hall, 1997)

Representasi adalah kegiatan membuat realitas namun bukan realitas yang sesungguhnya (Grossberg, 2006: 195). Konsep ini digunakan untuk menggambarkan ekspresi hubungan antar teks iklan (media) dengan realitas. Representasi secara literal bermakna "penghadiran kembali" atas sesuatu yang terjadi sebelumnya, melakukan mediasi dan memainkannya kembali untuk menggambarkan hubungan antara 
teks media dengan realitas. Representasi pun dapat berarti penggambaran dunia sosial dengan cara yang tidak lengkap dan sempit.

Jadi, representasi merupakan proses di mana para anggota sebuah budaya menggunakan bahasa untuk memproduksi makna. Bahasa dalam hal ini didefinisikan secara lebih luas, yaitu sebagai sistem apapun yang menggunakan tanda-tanda. Tanda di sini dapat berbentuk verbal maupun nonverbal. Pengertian tentang representasi tersebut memilki makna tetap atau makna asli (the true meanings) yang melekat pada dirinya, Masyarakatlah yang menjadikan hal tersebut menjadi memiliki makna,

Dipaparkan bahwa representasi adalah kegiatan membuat realitas, namun bukanlah realitas yang sesungguhnya (Grossberg, 2006:195). Konsep ini digunakan untuk menggambarkan eksperesi hubungan antara teks iklan (media) dengan realitas. Maka representasi yang dimaksud dalam tulisan ini adalah berusaha melihat realitas yang dibangun dalam suatu kreatif iklan.

\section{METODE PENELITIAN}

Jenis penelitian yang digunakan dalam penelitian ini menggunakan penelitian deskriptif kualitatif dengan paradigma kritis. Secara operasional penelitian ini menggunakan metode seimotika untuk menganalisa obyek peneleitian, objek penelitian dalam penelutian ini merupakan iklan Grab dengan format iklan video. Metode penelitian semiotika merupakan metode yang menganalisis kehidupan berdasarkan pada tanda-tanda yang ada pada masyarakat (Utomo et al., 2018). Metode ini pertama kali diperkenalkan oleh Ferdinand De Saussure pada tahyb 1857-1913 (Laughey, 2007). Makna semiotika diadopsi dari Bahasa Yunani, semion yang berarti tanda (Laughey, 2007). Dalam metode semiotika yang diperkenalkan oleh Ferdinand De Saussure ini memiliki beberapa aspek diantaranya adalah tanda (sign) yang dikategorikan lagi menjadi dua aspek yaitu penanda (significant) dan petanda (signified) (Utomo et al., 2018).

Pada penanda dapat diartikan sebagai bentuk/wujud fisik (Utomo et al., 2018). Penanda dapat berupa bunyi, gambar, huruf, visual, dan lainnya (Laughey, 2007). Sedangkan pertanda merupakan konsep atau makna dari apa yang ditandai (Laughey, 2007). Adapun relasi antara keduanya memiliki sifat "diadaadakan" (arbitrary) yang memiliki marna bahwasanya tidak terdapat relasi yang memiliki sifat alamiah antara penanda dan pertanda (Utomo et al., 2018. Namun demikian, relasi bersifat "diada-adakan' terikat oleh konvensi atau struktur.

Secara epistemologis, Saussure mendeskripsikan semiotika sebagai ilmu yang mempelajari mengenai tanda sebagai bagian dari kehidupan sosial. Oleh Saussure, semiotika kemudian dikembangkan menjadi interaksi tripartit yakni tanda (sign) dimana merupakan perpaduan dari penanda (signifier) \& petanda (signified) (Hartley, 2003). Semiotika berfokus pada teks karena ia dikhususkan untuk menganalisis bagaimana sistem makna menciptakan makna melalui teks. Namun seiring perkembangannya, perhatian yang lebih besar telah diberikan pada peran pembaca dalam merealisasikan atau menghasilkan makna dari sumber tekstual dengan cara yang interaktif.

Oleh karena itu, semiotika dimulai dengan memperlihatkan bagaimana teks terstruktur pengerjaan ulang tanda, kode, dan seterusnya berdasarkan sistem tanda khusus mereka dan bagaimana struktur ini menghasilkan mitos, konotasi, dan sebagainya (Hartley, 2003). Dalam penelitian ini penulis melakukan analisa semiotika dengan menelaah karakter-karakter yang terdapat pada iklan Grab. Pada iklan grab diposisikan sebagai teks yang terdiri dari karakter yang berbeda. Karakter tersebut hadir dalam bentuk suara, gambar, teks, dan adengan pada iklan Grab. Pada tahapan hasil penelitian, peneliti menganalisa berdasarkan makna denotatif, dan makna konotatif yang dilanjutkan dengan pembahsanan hasil penelitian dengan teori yang relevan. 


\section{HASIL DAN PEMBAHASAN}

HASIL

Pada bagian penelitian ini, penulis memaparkan hasil temuan dari analisa iklan Grab terkait dengan representasi rasisme terhadap ojek online. Penulis meganalisa objek penelitian yaitu iklan Grab dengan menggunakan metode analisa semiotika. Dimana penulis melihat karakter-karakter yang berbeda dalam video iklan Grab. Penulis menganalisa karakter yang berupa gambar, suara, teks, dan lainnya dengan mengulas makna secara denotasi, dan konotasi. Adapun hasil temuan dalam penelitian ini terdapat lima scene iklan yang dianalisis sebagai berikut.

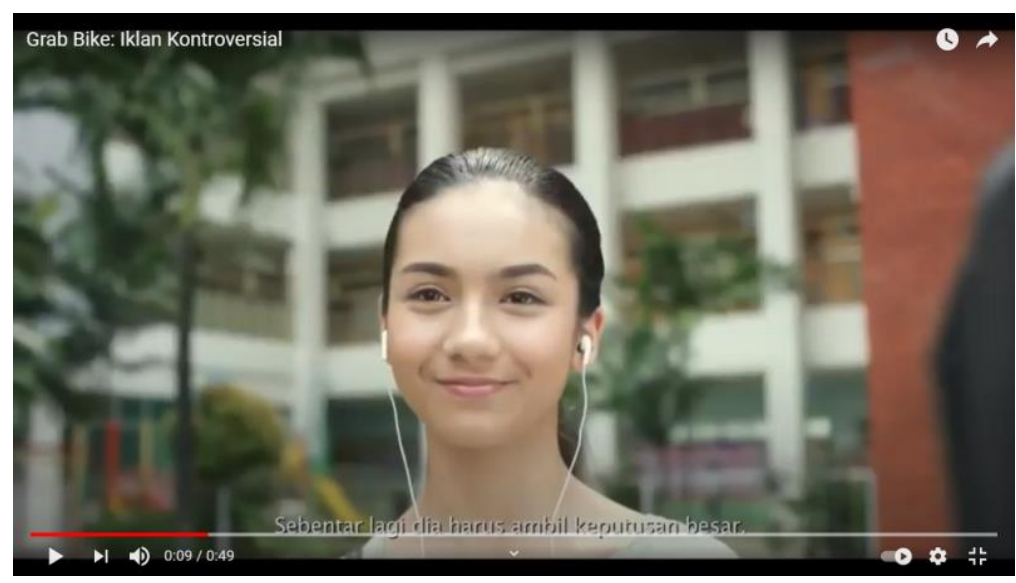

Gambar 1. Secene 1 Iklan Grab

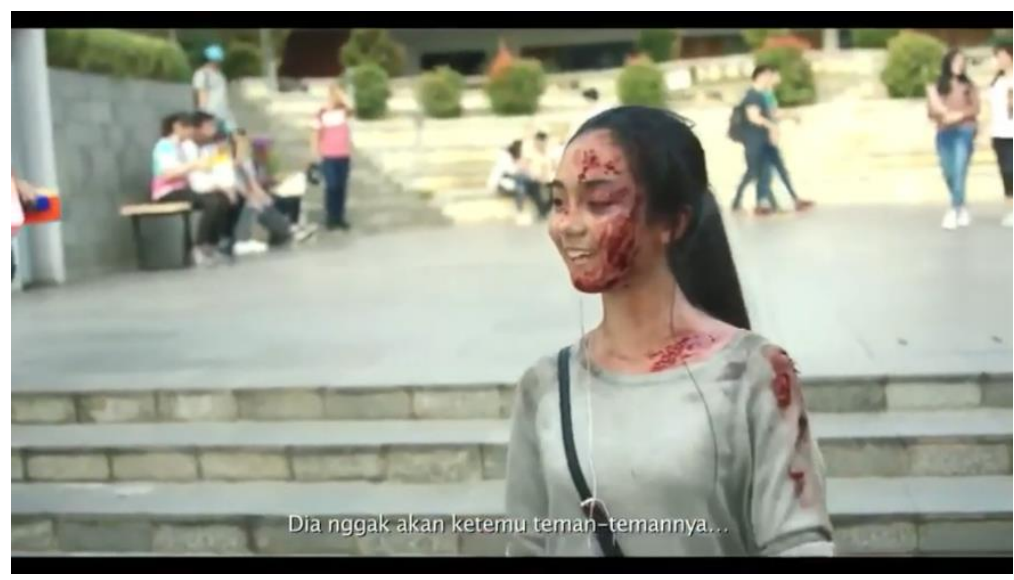

Gambar 2. Secene 2 Iklan Grab

Pertama penulis mengkomparasikan, gambar 1 dan gambar 2 yang memiliki makna secara denotasi dan konotasi pada iklan grab sebagai bentuk representasi marjinalisasi terhadap ojek konvensional. Pada scene 1 dan scene 2 merupakan himpunan scene yang menceritakan aktor memilih pilihan yang tepat dalam hidupnya. Apabila ditelaah berdasarkan makna denotasi, pada scene 1 menggambarkan aktor yang bernama Dinda yang merupakan seorang mahasiswa perempuan memiliki cita-cita besar sebagai seorang penyanyi. Dalam scene ini, Dinda sedang berjalan untuk pulang kembali kerumah. Pada scene 2 menunjukkan wajah Dinda yang terluka dan berdarah-darah. Teks yang tertera dalam iklan pada scene 2 ini menampilkan teks yang memiliki makna apabila salah memilih, Dinda tidak bisa bertemu dengan kedua orangtuanya dan teman-temannya. Apabila dianalisa berdasarkan aspek konotasi, pada scene 1 dan scene 2 ini menggambarkan bagaimana rasisme iklan yang ditayangkan oleh grab. Iklan tersebut mengandung pesan bahwasanya orang yang menggunakan ojek konvensional tidak akan selamat dan akan 
terluka. Padahal pada kenyataannya kita belum tentu tahu apa yang akan terjadi di masa depan, hal ini menjadi mitos dalam scene 1 dan 2. Mitos terkait keselamatan seseorang tidak ditentukan oleh manusia.

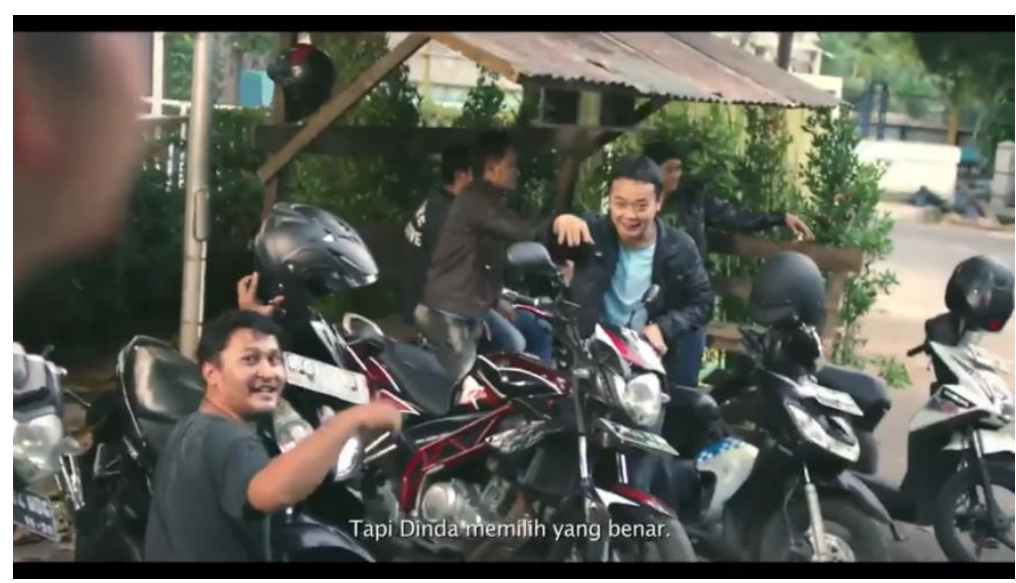

Gambar 3. Scene 3. Iklan Grab

Secara makna denotasi pada gambar 3. Sceme 3. Iklan Grab menunjukkan beberapa ojek konvensional yang sedang berada di pangkalan ojek. Sejumlah ojek konvensional terlihat sedang menyambut dinda dan mengajaknya untuk ikut memilih mereka untuk mengantar pulang.Namun dalam teks memunculkan kalimat "tapi Dinda memilih yang benar." Artinya Dinda memilih tidak menggunakan ojek konvensional dan lebih memilih pada ojek online yaitu Grab. Secara makna konotasi yang dilakukan oleh Dinda merupakan bentuk marjinalisasi dan ketidakpercayaan Dinda terhadap ojek konvensional, hal inilah yang kemudian membentuk stereotype di masyarakat bahwasanya ojek konvensional tidak dapat lagi dihandalkan di kalangan masyarakat. Mitos dalam bagian scene ini, tidak semua orang yang kita anggap profesional itu memang benar-benar profesional.

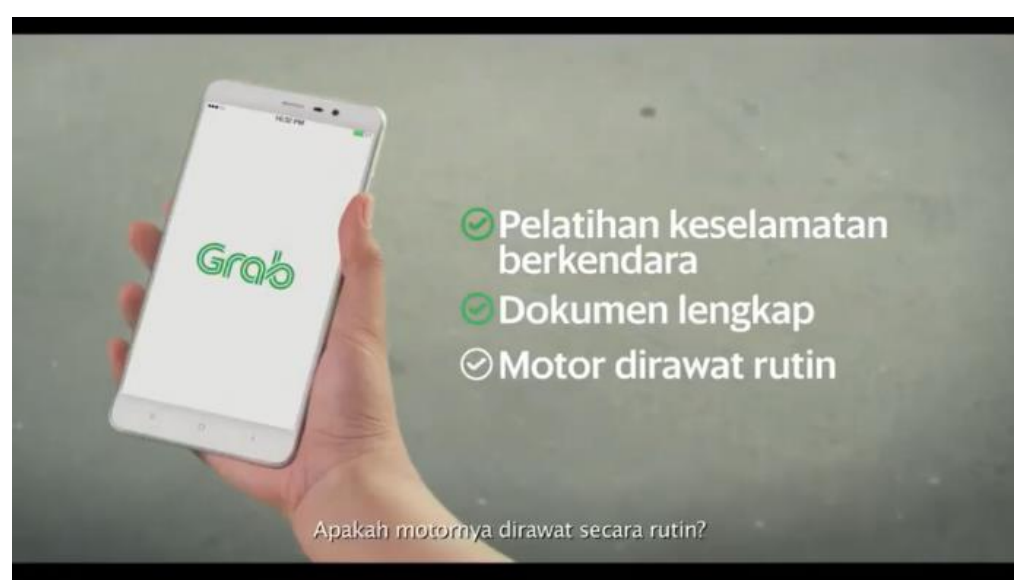

Gambar 4. Scene 4 Iklan Grab 


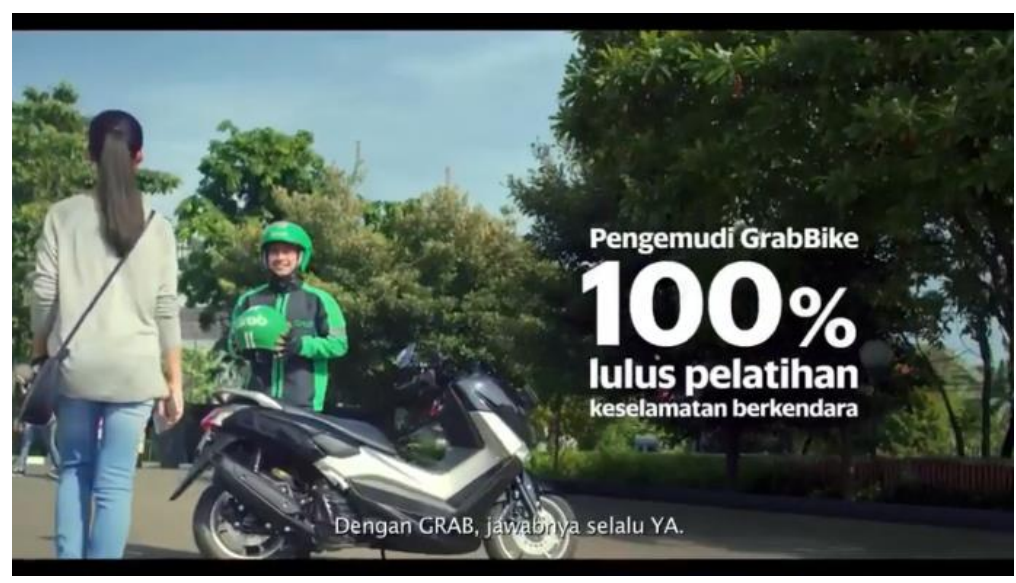

Gambar 5. Scene 5 Iklan Grab

Pada gambar 4 meliputi scene 4 dan scene 5 Iklan Grab, secara denotasi pada scene 4 memperlihatkan smartophone yang sedang membuka aplikasi Grab. Pada scene 4 terdapat teks dalam video yang menunjukkan teks sebagai berikut "Pelatihan keselamatan berkendara," "dokumentasi lengkap," "motor dirawat rutin." Sedangkan pada scene 5 secara denotasi menggambarkan aktor pemeran utama bernama Dinda dengan pengendara Grab yang sedang tersenyum menyapa sambil mengangkat helm berwarna hijau yang akan diberikan ke Dinda. Pada scene tersebut terdapat teks "Pengemudi Grabbike 100\% lulus pelatihan keselamatan berkendara." Sedangkan secara konotasi Dinda lebih memilih menggunakan ojek online yaitu grab dibandingan dengan ojek konvensional. Hal ini kemudian membangun stereotype di masyarakat terhadap keburukan ojek konvensional. Bahwasannya dengan menggunakan ojek konvensional seseorang tidak akan selamat atau bahkan malah merugi. Hal ini lah yang kemudian memunculkan pesan rasisme terhadap sebuah jasa dari dampak periklanan. Dengan hal ini ojek konvensional menjadi tidak lagi diminati masyarakat dan kebanyakan pekerjanya harus beralih pekerjaan.

\section{PEMBAHASAN}

Pada dasarnya, tanda dalam iklan terdiri dari tanda-tanda verbal dan nonverbal. Tanda verbal mencakup bahasa yang kita kenal sedangkan tanda-tanda nonverbal adalah bentuk dan warna yang disajikan dalam iklan, yang secara khusus meniru rupa atas bentuk realitas (Evelyn et al., 2019). Dalam hal penerapan semiotika pada tanda nonverbal, yang penting untuk diperhatikan adalah pemahaman tentang bidang nonverbal. Pada saat yang sama perlu disadari bahwa banyak peristiwa dan perilaku nonverbal ini ditafsirkan melalui simbol-simbol verbal (Reyhan et al., 2021). Bidang nonverbal adalah suatu wilayah yang menekankan pentingnya fenomena yang bersifat empiris, faktual dan konkret tanpa ujaran bahasa.

Dalam iklan grab menyajikan tanda-tanda iklan yang sesuai dengan realitas di masyarakat. Hal ini dinilai berdasarkan pada representasi iklan. Representasi adalah kegiatan membuat realitas namun bukan realitas yang sesungguhnya (Grossberg, 2006). Representasi berarti menggunakan bahasa untuk menyatakan sesuatu secara bermakna, atau mempresentasikan pada orang lain. Representasi merupakan bagian penting dalam proses di mana bahasa diproduksi dan dipertukarkan di antara simbol-simbol yang ada. Representasi melibatkan penggunaan bahasa dalam tanda-tanda (sign-sign) dan image-image yang mewakili atau mempresentasikan sesuatu (Hall, 1997). Konsep ini digunakan untuk menggambarkan ekspresi hubungan antar teks iklan (media) dengan realitas.

Realitas yang terjadi terkait dengan keberadaan ojek mengalami pertumbuhan dan perkembangan yang sangat cepat. Terutama di era digitalisasi dikembangkan, kemudahan akes teknologi, informasi, dan komunikasi hadir dengan mudah sehingga hal ini dapat merubah kehidupan secara fundamental (F et al., 2020). Hadirnya ojek online di adaptasi dari kebutuhan masyarakat yang semakin meningkat terhadap 
ketergantungan ojek, namun pada realitasnya ojek konvensional tidak diakui sebagai jenis kendaraan transportasi umum oleh pemerintah sehingga banyak resiko dalam penggunaan ojek konvensional.

Perkembangan teknologi kemudian merubah konsep ojek konvensional menjadi ojek online dengan sistem berupa aplikasi yang terintegrasi dengan teknologi, informasi, dan komunikasi (Winata, 2012). Dengan demikian kemudahan terhadap akses transportasi masyarakat terhadap ojek semakin meningkat. Terlebih lagi sudah terdapat jaminan bagi konsumen terhadap penggunaan jasa ojek online.

Selaras dengan iklan yang dibuat oleh Grab, dimana iklan tersebut menampilkan serta membandingkan perbedaan antara ojek online miliknya dengan ojek konvensional. Dimana pada scene 1 hingga scene 5 yang dianalisa oleh penulis menggambarkan bagaimana rasisme iklan grab terhadap ojek konvensional. Pada gambar scene 1 hingga scene 5 menceritakan bagaimana ojek konvensional lebih tidak profesional dibangdingan dengan ojek online. Dengan ojek online, konsumen yang menggunakannya akan terasa lebih aman dan lebih nyaman. Hal ini dilihat berdasarkan pada lisensi keamanaan yang dimiliki oleh driver, namun hal ini belum tentu menjadi jaminan keselamatan. Selain itu, penggunaan ojek online lebih efektif, efisien baik secara waktu dan harga sebab sudah ditentukan secara langsung oleh perusahaan terkait dengan tarif dan ketepatan waktu sampai tempat tujuan.

Penulis meganalisa hasil dari pembahasan dalam penelitian ini menunjukkan bahwasanya terdapat pesan yang mengandung bias marjinalisasi dalam iklan Grab. Hal ini menjadi representasi rasisme iklan di masyarakat. Meskipun iklan pada kenyataannya mengambil realitas yang terjadi di masyarakat. Namun, ketika hal ini diangkat dalam sebuah iklan, hal ini kemudian menjadi pada realitas iklan dan justru akan membangun stereotype baru yang merubah pandangan masyarakat terhadap suatu jasa atau produk yang di iklankan.

Penelitian ini mempunyai kesenjangan penelitian bahwasanya belum ada penelitian yang membahas terkait dengan representasi iklan rasisme terhadap iklan Grab. Penelitian-penelitian terdahulu sebelumnya kebanyakan membahas representasi rasisme berdasarkan pada warna kulit, ras, dan gologongan. Sehingga penelitian ini dianggap sebagai keterbaharuan penelitian karena belum banyak yang membahas terkait dengan penelitian ini.

\section{KESIMPULAN}

Perkembangan teknologi mengubah konsep ojek konvensional menjadi ojek online dengan sistem berupa aplikasi yang terintegrasi dengan teknologi, informasi, dan komunikasi. Dengan demikian kemudahan terhadap akses transportasi masyarakat terhadap ojek semakin meningkat. Terlebih lagi sudah terdapat jaminan bagi konsumen terhadap penggunaan jasa ojek online. Realitas yang terjadi terkait dengan keberadaan ojek mengalami pertumbuhan dan perkembangan yang sangat cepat. Hadirnya ojek online di adaptasi dari kebutuhan masyarakat yang semakin meningkat terhadap ketergantungan ojek, namun pada realitasnya ojek konvensional tidak diakui sebagai jenis kendaraan transportasi umum oleh pemerintah sehingga banyak risiko dalam penggunaan ojek konvensional.

Hasil analisa pembahasan pada temuan penelitian terkait dengan representasi marjinalisasi Iklan Grab terhadap ojek konvensional bahwasanya terdapat unsur yang mengandung pesan marjinalisasi setelah dianalisa menggunakan metode semiotika. Hasil analisa dimulai dengan menggali makna tanda-tanda dalam video iklan Grab mulai dari scene 1 hingga scene 5 secara denotasi dan konotasi. Adapun dalam iklan tersebut mengandung pesan bahwasannya ojek konvensional tidak professional dibandingkan dengan ojek online melalui Grab. Dengan menggunakan ojek online, konsumen akan lebih aman karena sudah terdapat lisensi pada pengemudi sehingga keselamatannya akan lebih terjamin dibandingkan dengan menggunakan ojek konvensional. Keterbatasan pada penelitian ini hanya menganalisa bagaimana marjinalisasi terjadi pada ojek online dengan ojek konvensional. Namun, penelitian serupa yang 
membahas terkait dengan representasi marjilanisasi terhadap Iklan Grab belum banyak yang membahasnya. Rekomendasi untuk penelitian selanjutnya, penulis merekomendasikan untuk membahas secara lebih mendalam dan lebih mendetail terkait dengan objek penelitian, terlebih lagi bisa dibandingkan dengan studi kasus iklan dari negara lain yang menggunakan aplikasi serupa.

\section{PERSANTUNAN}

Penulis mengucapkan terima kasih kepada Dr. Fajar Junaedi yang telah membimbing dalam proses penyeleseian artikel ini hingga terbitnya artikel nanti. Adapun judul artikel ini yaitu dengan judul Representasi Marjinalisasi Iklan Grab terhadap Ojek Konvensional. Artikel ini dibuat sebagai bentuk luaran dari mata kuliah Kajian Kritis Iklan pada program studi Ilmu Komunikasi UMY selama satu semester genap tahun 2020/2021.

\section{REFERENSI}

Aron, L., Botella, M., \&Lubart, T. (2019). Culinary arts: Talent and their development. In R. F. Subotnik, P. Olszewski-Kubilius, \& F. C. Worrell (Eds.), The psychology of high performance: Developing human potential into domain-specific talent (pp. 345-359). American Psychological Association. https://doi.org/10.1037/0000120-016

Bungin, M. B. (2008). Konstruksi Sosial Media Massa. Jakarta: Kencana.

Evelyn, A., Priyowidodo, G., \& Budiana, D. (2019). Representasi Rasisme dalam Film Woodlawn. 7(1), 113. http://publication.petra.ac.id/index.php/ilmu-komunikasi/article/view/9686

F, A. R., Abidin, Z., Lubis, F. O., Komunikasi, I., \& Karawang, U. S. (2020). TERHADAP ORANG KULIT HITAM DALAM FILM BLACKKKLANSMAN Korespondensi Penulis : 14(2).

Hariningsih, Endah. 2013. Internet Advertising sebagai Sarana Komunikasi Pemasaran Interaktif. Jurnal Bisnis, Manajemen, dan Administrasi Vol.1(2)

McKinney, C., \& Smith, N. (2005). TeTiriti o Waitangi or The Treaty of Waitangi: What is the difference? In D. Wepa (Ed.), Cultural safety in Aotearoa New Zealand (pp. 39-57). Auckland, New Zealand: Pearson Education New Zealand.

Putra, Algamar. 2017. Pengaruh Iklan dan Kepercayaan Merek Terhadap Minat Beli Konsumen (Studi Pada Texas Chicken Pekanbaru). Jurnal Online Mahasiswa FISIP Universitas Riau Vol.4(1)

Reyhan, M. N., Almubasysyir, R., \& Febriansyah, M. (2021). Representasi Rasisme Warna Kulit dalam Iklan Lotion Dove. Jurnal Audiens, 2(1). https://doi.org/10.18196/jas.v2i1.8830

Sasongko, Y. P. D., \& Marta, R. F. (2018). Ekspresiidentitasmelaluirelasi ayah dananakpadaiklan youtube grab official. Bricolage: Jurnal Magister IlmuKomunikasi, 4(2), 118-132.

Utomo, K. D., Jupriono, J., \& Ayodya, B. P. (2018). Film Dokumenter Gerakan Merekam Kota Karya Gresik Movie: Telaah Semiotika John Fiske. Representamen, 4(02), 1-7. https://doi.org/10.30996/.v4i02.1735

Winata, I. N. (2012). Hegemoni Maskulinitas Dalam Iklan Minuman Berenergi (Analisis Semiotika Extra Joss Dan Kuku Bima Ener-G). Jurnal Ilmiah Komunikasi, 3(1), 42-49. http://jurnal.unpand.ac.id/index.php/dinsain/article/view/95/92 